\title{
Development of the Fe-Ni Anodic Catalyst for Solid Oxide Fuel Cell Operated at Intermediate-temperature Direct Utilizing of Dimethylether Fuel
}

\author{
Ryosuke TAI, ${ }^{a}$ Koichi UI, ${ }^{b}$ Ken TAKeuchi, ${ }^{c, *}$ Kenjiro Fujimoto, ${ }^{a}$ and Shigeru Ito ${ }^{c}$
}

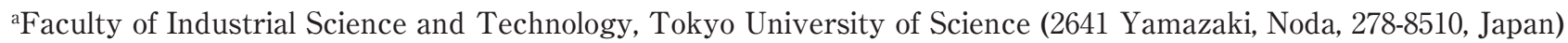 \\ ${ }^{b}$ Frontier Materials and Function Engineering, Graduate School of Engineering, Iwate University (13-18-8 Ueda, \\ Morioka, Iwate, 020-8550, Japan) \\ 'Faculty of Science and Technology, Tokyo University of Science (102-1 Tomino, Oshamanbe, 049-3514, Japan)
}

Received September 1, 2008 ; Accepted January 16, 2009

\begin{abstract}
The Fe, Ni-BCY20 and Fe-Ni catalysts were used as the materials for anode of an intermediate-temperature Solid Oxide Fuel Cell (SOFC) for direct utilization of dimethylether(DME) gas fuel. A proton conducting oxide $\mathrm{BaCe}_{0.8} \mathrm{Y}_{0.2} \mathrm{O}_{3-\delta}$ was employed as the electrolyte(thickness $500 \mu \mathrm{m}$ ) and a Pt was applied as the cathode. The cell was operated at $600{ }^{\circ} \mathrm{C}$. The maximum power density of the cell with the Fe9-Nil anode that has 9/1 molar ratio of $\mathrm{Fe}$ to $\mathrm{Ni}$ was $46.4 \mathrm{~mW} \mathrm{~cm}^{-2}$ at $80 \mathrm{~mA} \mathrm{~cm}^{-2}$. The Fe9-Nil anode showed remarkable improvement of cell performance in comparison with the Fe anode that we reported before.
\end{abstract}

Key Words : SOFC, Dimethylether (DME), Proton Conducting Oxide, Anode

\section{Introduction}

Solid Oxide Fuel Cell (SOFC) has higher power generation efficiency and more fuel flexibility than other fuel cells and is developed for practical use. ${ }^{1)}$

However, existing SOFC were operated at about $1000{ }^{\circ} \mathrm{C}$. High operating temperatures precludes the use of inexpensive metal components as interconnects. It also produces thermal stresses and solid-phase reactions.,3) Furthermore, using hydrogen as fuel is impractical in terms of storage and handling. 4.5$)$

Recently, many researchers make an effort to operate SOFC at intermediate-temperatures $\left(600{ }^{\circ} \mathrm{C}-800{ }^{\circ} \mathrm{C}\right)$ and to accomplish direct utilization of hydrocarbon fuel at the same time. ${ }^{6-9)}$ In order to enable fuel cells to operate at intermediate-temperatures, it is necessary to develop the electrolyte that has high ionic conductivity at these temperatures. Iwahara, et al. reported that $\mathrm{BaCe}_{0.8} \mathrm{Y}_{0.2} \mathrm{O}_{3-\delta}$ (BCY20) showed about $3 \cdot 10^{-2} \mathrm{~S} \mathrm{~cm}^{-1}$ ionic conductivity ${ }^{10}$ at $600{ }^{\circ} \mathrm{C}$ and transference number of proton was almost one. ${ }^{11)}$ That is the reason why we regarded BCY20 as suitable electrolyte for intermediate SOFC.

Dimethylether (DME) is one of the candidates for fuel of the intermediate SOFC. First, DME gas becomes easily liquid with high pressure, second it is easily oxidized at intermediate-temperatures ${ }^{18)}$ and finally it is possible for DME to use the existing infrastructure for propane gas. ${ }^{16,17)}$ Besides, because of high cetane number and environmentally-friendly, DME is regarded as promising resource for future low emission society. ${ }^{19)}$

We have developed the direct-DME fuel cell operated at intermediate-temperature using BCY20 as a solid electrolyte. It was found that $\mathrm{Fe}$, which is inexpensive material, showed excellent performance as a catalyst. ${ }^{23)} \mathrm{Fe}$ catalyst decomposes DME to $\mathrm{H}_{2}, \mathrm{CO}$ and $\mathrm{CH}_{4}$ at $600{ }^{\circ} \mathrm{C}$. $\mathrm{H}_{2}$ and $\mathrm{CO}$ could be used as the fuels in this SOFC, however most of $\mathrm{CH}_{4}$ was not used. Perry Murray et al. ${ }^{20}$ reported a high catalytic activity of $\mathrm{Ni}$, which is also inexpensive material as well as $\mathrm{Fe}$, for $\mathrm{CH}_{4}$ decomposition in a direct-methane fuel cell.

In this study, the addition of $\mathrm{Ni}$ to $\mathrm{Fe}$ anode was investigated to improve the cell performance of the SOFC for direct utilization of DME at $600{ }^{\circ} \mathrm{C}$.

\section{Experimental}

$\mathrm{BaCe}_{0.8} \mathrm{Y}_{0.2} \mathrm{O}_{3-\delta}(\mathrm{BCY} 20)^{21)}$ powder was pressed in a pellet with $20 \mathrm{~mm}$ in dia. This pellet was sintered at $1600^{\circ} \mathrm{C}$ for $12 \mathrm{~h}$ in air. The sintered pellet was polished to 0.5 $\mathrm{mm}$ in thick, and was used as the solid electrolyte. As a cathode, Pt paste (TR-7905, Tanaka precious metals) was applied with $8 \mathrm{~mm}$ in dia. to one side of the pellet and was calcined at $930{ }^{\circ} \mathrm{C}$ for $1 \mathrm{~h}$ in air. Three kinds of anode materials were prepared: Fe, Ni-BCY20 and Fe-Ni. $\mathrm{Fe}_{2} \mathrm{O}_{3}$ paste was prepared by mixing $\mathrm{Fe}_{2} \mathrm{O}_{3}$ powder (Aldrich) with a binder (TMS-1, Tanaka precious metals). NiO-BCY20 paste was prepared from $\mathrm{NiO}$ powder (Aldrich), BCY20 powder and TMS-1. $\mathrm{Fe}_{2} \mathrm{O}_{3}$ - $\mathrm{NiO}$ paste was prepared from $\mathrm{Fe}_{2} \mathrm{O}_{3}$ powder (Aldrich), $\mathrm{NiO}$ powder (Aldrich) and TMS-1. These pastes were applied with 8 $\mathrm{mm}$ in dia. to the other side of the BCY 20 pellet and were calcined at $800{ }^{\circ} \mathrm{C}$ for $1 \mathrm{~h}\left(\mathrm{Fe}_{2} \mathrm{O}_{3}\right)$, at $1300{ }^{\circ} \mathrm{C}$ for 1.5 $\mathrm{h}(\mathrm{NiO}-\mathrm{BCY} 20)$ or at $900{ }^{\circ} \mathrm{C}$ for $2 \mathrm{~h}\left(\mathrm{Fe}_{2} \mathrm{O}_{3}-\mathrm{NiO}\right)$ in air. Before the electrochemical measurements, these oxides were reduced to $\mathrm{Fe}, \mathrm{Ni}-\mathrm{BCY} 20$ and $\mathrm{Fe}-\mathrm{Ni}$ in $\mathrm{H}_{2}$ gas at $600{ }^{\circ} \mathrm{C}$. In Fe-Ni anodes, four samples were prepared with the molar ratio of $\mathrm{Fe}$ to $\mathrm{Ni}$ was $9 / 1,8 / 2,7 / 3$ and 5/5. The electrodes were denoted as Fe9-Ni1, Fe8-Ni2, Fe7$\mathrm{Ni3}$, and Fe5-Ni5, respectively. Single cell consisted of the BCY20 electrolyte with the anode and the cathode. DME gas or $\mathrm{CH}_{4}$ gas was bubbling into water under the flow rate of $50 \mathrm{ml} \mathrm{min}{ }^{-1}$ at $35^{\circ} \mathrm{C}$, and then they were supplied to the anode side. Dry air was supplied to the cathode side with the flow rate of $100 \mathrm{ml} \mathrm{min}{ }^{-1}$. V-I characteristics 
of each cell were measured by using a galvanostat (NPGFZ-251-B, Nikko Keisoku)at $600{ }^{\circ} \mathrm{C}$.

\section{Result and Discussion}

In a previous study, ${ }^{23)}$ we reported that $\mathrm{Fe}$ anode showed higher performance than Ni-BCY20 anode ; with the Ni-BCY20 anode, the open circuit voltage (OCV) was $0.87 \mathrm{~V}$ and the maximum power density was $5.5 \mathrm{~mW} \mathrm{~cm} \mathrm{~cm}^{-2}$. On the other hand, with the Fe anode, the OCV was 0.97 $\mathrm{V}$ and the maximum power density was $36.4 \mathrm{~mW} \mathrm{\textrm {cm } ^ { - 2 }}$ using DME as fuel at $600{ }^{\circ} \mathrm{C}$. As a result of examination for figuring out the reaction mechanism of DME in the cell with a $\mathrm{Fe}$ anode at $600{ }^{\circ} \mathrm{C}$, we found that DME decomposed to $\mathrm{H}_{2}, \mathrm{CO}$ and $\mathrm{CH}_{4}$ on the $\mathrm{Fe}$ anode. However, $\mathrm{CH}_{4}$ did not have anodic reaction on $\mathrm{Fe}$ while $\mathrm{H}_{2}$ and $\mathrm{CO}$ did. It means that $\mathrm{CH}_{4}$ that produced from DME was not used as fuel for the cell with $\mathrm{Fe}$ anode. It is necessary to use $\mathrm{CH}_{4}$ as fuel for bringing out the potential capability of DME, then, we started finding suitable catalyst for $\mathrm{CH}_{4}$. Perry Murray et al. ${ }^{20)}$ reported a high catalytic activity of $\mathrm{Ni}$ for $\mathrm{CH}_{4}$ decomposition in a direct-methane fuel cell. Therefore, the addition of Ni to $\mathrm{Fe}$ anode was investigated to improve the cell performance in this study.

Figure 1 shows the $V-I$ characteristics measured using $\mathrm{Fe}$ and Ni-BCY20 anodes with supplying $\mathrm{CH}_{4}$ gas to the anode side. The SOFC with the Fe anode indicated 0.25

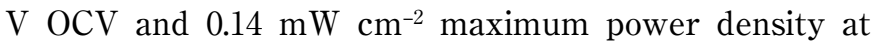
$1.0 \mathrm{~mA} \mathrm{~cm}^{-2}$. On the other hand, the SOFC with the NiBCY20 anode show $0.72 \mathrm{~V} \mathrm{OCV}$ and the $0.38 \mathrm{~mW} \mathrm{~cm}^{-2}$ maximum power density at $1.0 \mathrm{~mA} \mathrm{~cm}-2$. It was confirmed that the cell performance with the Ni-BCY20 anode was superior to the $\mathrm{Fe}$ anode using $\mathrm{CH}_{4}$ as a direct fuel at $600{ }^{\circ} \mathrm{C}$.

We especially call your attention to the fact that $\mathrm{OCV}$ using Ni-BCY20 anode was much higher than Fe anode. The higher OCV of Ni-BCY20 anode can be explained following mechanism.

When proton conducting oxides are used as electrolyte, electromotive force (EMF) is represented by the following Eq. 1, 2, 3 and $4^{22)}$;

$$
\begin{gathered}
E=-\frac{2 F}{\Delta G} \\
\Delta G=-R T \ln K \\
K=\frac{p\left(\mathrm{H}_{2} \mathrm{O}\right)^{2}}{p\left(\mathrm{O}_{2}\right) p\left(\mathrm{H}_{2}\right)^{2}} \\
p\left(\mathrm{H}_{2}\right)=p\left(\mathrm{H}_{2}, \mathrm{a}\right)
\end{gathered}
$$

$F$ is Faraday constant, $T$ is temperature, $R$ is constant, $p\left(\mathrm{H}_{2} \mathrm{O}\right), p\left(\mathrm{O}_{2}\right)$, and $p\left(\mathrm{H}_{2}\right)$ is partial pressure on threephase-boundary (TPB) and $p\left(\mathrm{H}_{2}, \mathrm{a}\right)$ is partial pressure of hydrogen adsorbed on the catalyst in TPB.

Proceedings of steam reforming of $\mathrm{CH}_{4}$ shown in Eq. 5 increase the value of the partial pressure of $\mathrm{H}_{2} p\left(\mathrm{H}_{2}\right.$, a) in Eq. 4 and OCV, according these equations.

Therefore, the reason why Ni-BCY20 anode has higher

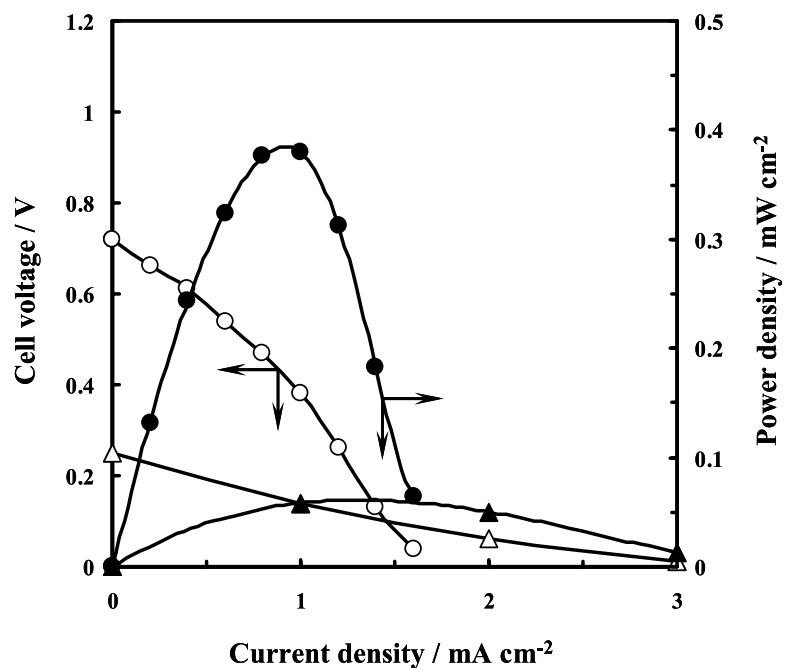

Fig. 1 Cell performance test with $\mathrm{CH}_{4}$ gas. Anode $\triangle, \boldsymbol{\Delta}$ : Fe $\bigcirc, \mathbf{O}:$ Ni-BCY 20.

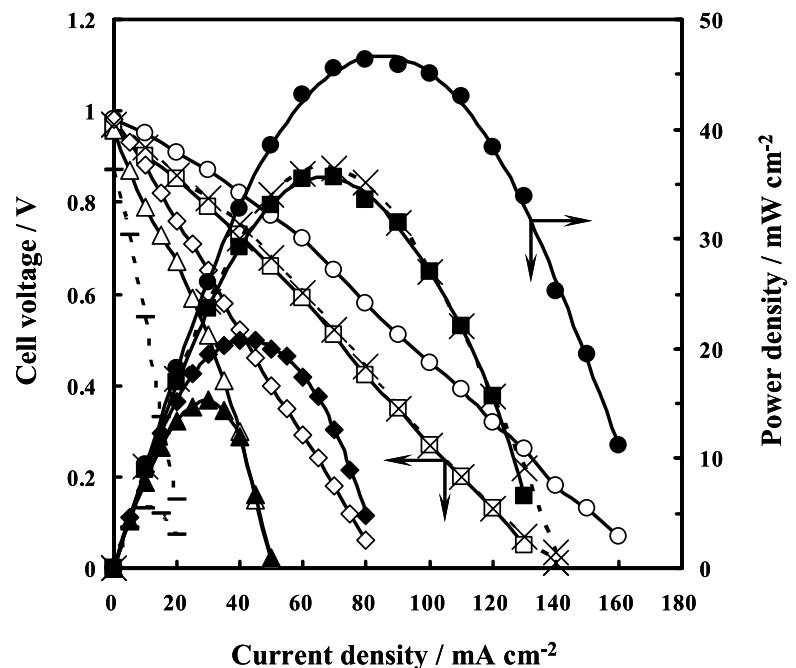

Fig. 2 Cell performance test with DME gas fuel. Anode $\times$ : Fe $\bigcirc, \bigcirc$ : Fe9-Ni1 $\square, \square$ : Fe8-Ni2 $\diamond, \diamond$ Fe7-Ni3 $\triangle, \boldsymbol{\Delta}:$ Fe5-Ni5 - : Ni-BCY20.

OCV is explained that the Ni-BCY20 anode accelerates the steam reforming reaction of $\mathrm{CH}_{4}$ in Eq 5 . It is the evidence that the catalytic activity of Ni-BCY20 for $\mathrm{CH}_{4}$ with steam is higher than that of Fe anode.

$$
\mathrm{CH}_{4}+\mathrm{H}_{2} \mathrm{O}=3 \mathrm{H}_{2}+\mathrm{CO}
$$

From these facts, we found that $\mathrm{Fe}$ anode was more effective for DME decomposition to $\mathrm{H}_{2}, \mathrm{CO}$ and $\mathrm{CH}_{4}$ but $\mathrm{Ni}$-BCY20 anode was more suitable for steam reforming of $\mathrm{CH}_{4}$. Therefore, we investigated $\mathrm{Fe}-\mathrm{Ni}$ bi-metal anode in order to improve catalytic activity for $\mathrm{CH}_{4}$ with keeping high catalytic activity of Fe for DME. We try to develop the material that accomplishes higher catalytic activity for both DME and $\mathrm{CH}_{4}$.

Figure 2 shows the $V-I$ characteristics measured using various $\mathrm{Fe}-\mathrm{Ni}$ anodes with supplying DME gas directly to the anode side. By using the Fe9-Nil anode, OCV of the cell was $0.98 \mathrm{~V}$ and the maximum power density of 


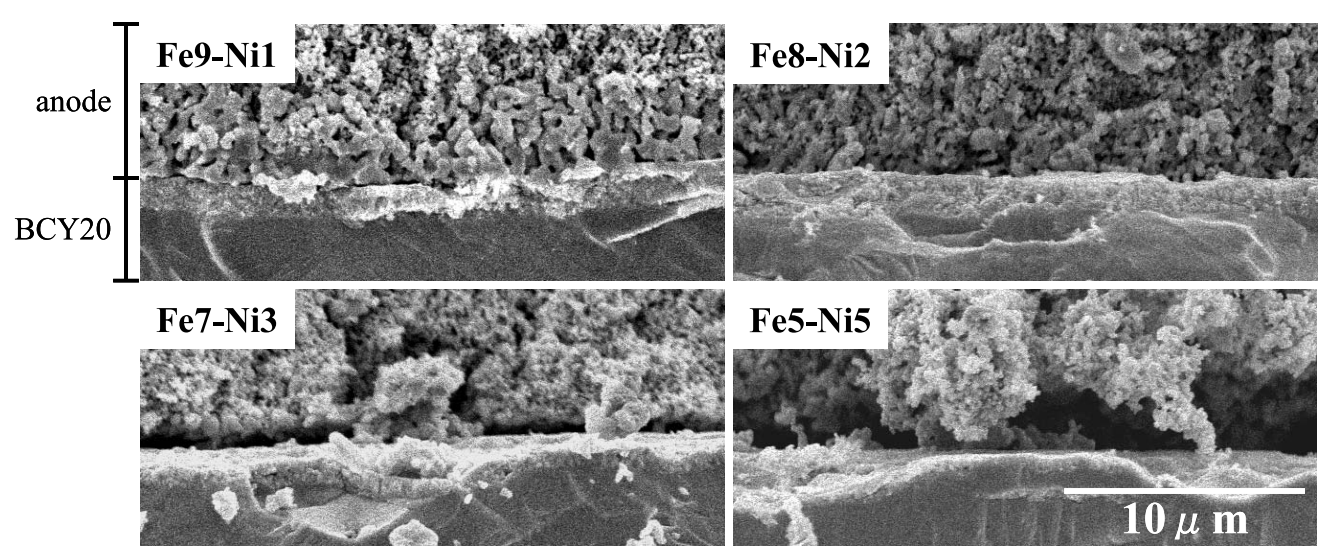

Fig. 3 SEM images of the cross section of various Fe-Ni anodes.

the cell was $46.4 \mathrm{~mW} \mathrm{~cm}^{-2}$ at $80 \mathrm{~mA} \mathrm{~cm}^{-2}$. The Fe9-Ni1 anode showed remarkable improvement of cell performance compared with the Fe anode. However, maximum power density was gradually decreased with increasing additive amount of $\mathrm{Ni} ; 35.7 \mathrm{~mW} \mathrm{~cm}^{-2}$ (Fe8-Ni2), $20.8 \mathrm{~mW}$ $\mathrm{cm}^{-2}$ (Fe7-Ni3), $15.3 \mathrm{~mW} \mathrm{~cm}^{-2}$ (Fe5-Ni5).

The reason $\mathrm{Fe}-\mathrm{Ni}$ anode showed superior performance is assumed that $\mathrm{Ni}$ in the anode promoted steam reforming of $\mathrm{CH}_{4}$ produced from DME and amount of $\mathrm{H}_{2}$ and $\mathrm{CO}$ which can use as fuel were increased.

Figure 3 shows that $\mathrm{Fe} 9-\mathrm{Ni} 1$ and $\mathrm{Fe} 8 \mathrm{-Ni} 2$ anodes have good adhesion to the BCY20 electrolyte. However, detachment of anode from BCY20 was observed for Fe7$\mathrm{Ni} 3$ and Fe5-Ni5 anodes. This result suggests that Ni hinders anode from sintering with BCY20 electrolyte, then excessive addition of $\mathrm{Ni}$ causes increasing of interface resistance. The decreasing of cell performances in Fe7$\mathrm{Ni} 3$ and Fe5-Ni5 anodes is explained by these SEM images.

The reason of improving cell performance with $\mathrm{Fe}-\mathrm{Ni}$ catalyst is following. First, Ni promotes steam reforming of $\mathrm{CH}_{4}$. Second, $\mathrm{Fe}$ prevents anode and the electrolyte from detaching because $\mathrm{Fe}$ has excellent sintering performance and it plays a role in holding $\mathrm{Ni}$ on the BCY20.

\section{Conclusion}

The Fe, Ni-BCY20 and Fe-Ni catalysts were investigated as the anodic materials of an intermediate-temperature SOFC for direct utilization of hydrocarbon fuel. BCY20 and Pt were used as the electrolyte and the cathode, respectively. The cell was operated at $600^{\circ} \mathrm{C}$. Using $\mathrm{CH}_{4}$ as a direct fuel, it was confirmed that the cell performance with the Ni-BCY20 anode was superior to the Fe anode. By impregnating with $\mathrm{Ni}$ catalyst to previous $\mathrm{Fe}$ anode, the cell performance was improved. And the Fe9-

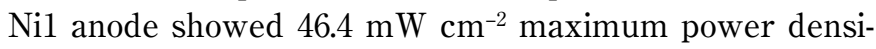
ty at $600{ }^{\circ} \mathrm{C}$.

\section{References}

1) J. P. P. Huijsmans, F. P. F. van Berkel, and G. M, Christie, J. Power Sources, 71, 107 (1998).

2) T. Ishihara, M. Honda, T. Shibayama, H. Minami, H. Nishiguchi, and Y. Takita, J. Electrochem. Soc., 145, 3177
(1998).

3) C. Lu, W. L. Worrell, R. J. Gorte, and J. M. Vohs, J. Electrochem. Soc., 150, A354 (2003).

4) T. Hibino, A. Hashimoto, T. Inoue, J. Tokuno, S. Yoshida, M. Sano, Science, 288, 2031 (2004).

5) G. A. Deluga, J. R. Salge, L. D. Schmidt, and X. E. Verykios, Science, 303, 993 (2004).

6) E. P. Murray, T. Tsai, S. A. Barnett, Nature, 400, 649 (1999).

7) S. Park, R. J. Gorte, and J. M. Vohs, J. Electrochem. Soc., 148, A443 (2001).

8) Y. Jiang and A. V. Virkar, J. Electrochem. Soc., 148, A706 (2001).

9) C. Lu, S. An, W. L. Worrell, J. M. Vohs, and R. J. Gorte, Solid State Ionics, 175, 47 (2004).

10) H. Iwahara, Solid State Ionics, 77, 289 (1995).

11) J. Guan, S. E. Dorris, U. Balachandran, and M. Liu, J. Electrochem. Soc., 145, 1780 (1998).

12) H. Taherparvar, J. A. Kilner, R. T. Baker, M. Sahibzada, Solid State Ionics, 162, 297 (2003).

13) T. Hibino, A. Hashimoto, M. Suzuki, and M. Sano, J. Electrochem. Soc., 149(11), A1503 (2002).

14) A. Tomita, T. Hibino, and M. Sano, Electrochem. SolidState Lett., 8, A333 (2005).

15) M. Koyama, C. -J. Wen, and K. Yamada, J. Electrochem. Soc., 147(1), 87 (2000).

16) E. P. Murray, S. J. Harris, and H. Jen, J. Electrochem. Soc., 149, A1127 (2002).

17) W. Shi-zhong and G. Jie, Electrochem. Solid-State Lett., 9, A395 (2006).

18) S. Wang, T. Ishihara, and Y. Takita, Appl. Catal., A, 228, 167 (2002).

19) C. M. R. Reyes, J. S. Francisco, J. J. Szente, M. M. Maricq, and L. F. Ostergaard, J. Phys. Chem. A, 109, 10940 (2005).

20) E. Perry Murray, T. Tsai, and S. A. Barnett, Nature Lett., 649 (1999).

21) K. Takeuchi, C. -K. Loong, J. W. Richardson Jr., J. Guan, S. E. Dorris, and U. Balachandran, Solid State Ionics, 138, 63 (2000).

22) H. Tagawa, Kotaisankabutu-nenryoudenti to Chikyukankyo, pp. 58, 59 pp. 177, 178 Agune Syoufuusya, (1998) [in Japanese].

23) Y. Ishida, R. Tai, K. Takeuchi, K. Fujimoto, and S. Ito, Denki Kagaku, [to be submitted] 